\title{
The Probabilistic Nature of Environmental Cracking in Candidate Waste Package Materials
}

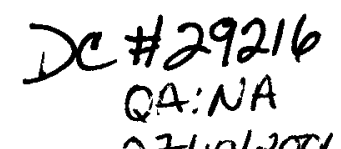

L.M. Young

GE Corporate Research \& Development

MOL. 20010913.0195

1 River Rd.

Schenectady, NY 12301

P.L. Andresen

GE Corporate Research \& Development

1 River Rd.

Schenectady, NY 12301

G.M. Gordon

Framatome Cegacts ADVANCED nuclear power

1211 1261 Town Center Dr.

Las Vegas, NV $89+3489144$

\begin{abstract}
The objective of this research is to determine the effects of material condition and applied stress on environmental cracking in candidate waste package materials for the Yucca Mountain Project. Time-to-failure experiments were performed on smooth bar tensile specimens in a hot, concentrated, mixed-salt solution chosen to simulate concentrated Yucca Mountain water. Smooth tensile specimens were individually loaded by the internal pressure of a 55-liter autoclave, where the applied stress varied with the individual specimen gauge cross section. The effects of material, applied stress, welding, surface finish, shot peening, cold work, crevicing, and aging treatment were investigated for Alloy 22, Titanium Grade 7, and 316NG stainless steel. Testing of multiple specimens allowed statistical differences among material conditions to be determined. Sensitized 304SS specimens were included in the test matrix to provide benchmark data. Microstructural effects on time-to-failure were studied for Alloy 22, where heat treatments designed to produce topologically close-packed phases (TCP) and long-range ordering (LRO) were investigated. This research complements high-resolution crack-growth-rate experiments performed in a parallel research project.
\end{abstract}

\section{Introduction}

General corrosion, localized corrosion, and stress corrosion cracking represent the most likely degradation modes for the waste package structural materials. The waste package corrosion behavior will be dominated by the local environment that forms on the waste package at temperatures above $\approx 75^{\circ} \mathrm{C}$, where the heat flux through the waste package is higher, the environments more concentrated, and the material susceptibility to corrosion degradation is highest. Since the waste package is always hotter than its surrounding environment, probably by several degrees at $75-120^{\circ} \mathrm{C}$, the solution concentration on the waste package surface will be at least several molar, and obviously a concentrated solution as the waste package initially cools to the temperature of the maximum boiling point elevation (of perhaps $120^{\circ} \mathrm{C}$ ). As the Yucca Mountain water drips or splashes onto the waste package and concentrates, the $\mathrm{pH}$ is expected to rise to at least 10 , and perhaps much higher.

This research study is designed to use a statistical approach in determining the life and reliability of proposed waste package materials potentially susceptible to stress corrosion cracking under conditions that are both relevant and likely to promote stress corrosion cracking, i.e., fairly high concentrations at fairly high temperatures. In these constant load experiments, the specimen failure versus time results are analyzed using the Weibull distribution, often used for time-to-failure analyses. Reliability data are commonly right-censored, meaning that some specimens do not fail during the test duration. The survivor information is useful and as such is included in the probabilistic analyses.

The experimental results provide a means of making probabilistic comparisons between material-conditions. These data are strengthened with laboratory crack growth data obtained in a parallel study. Other programs are addressing the general and localized corrosion in this and related environments. 


\section{Experimental Procedure}

Time-to-failure experiments are being performed on smooth tensile specimens that are individually loaded by the internal pressure of a large "Keno" autoclave. Figure 1 schematically shows a cross section of a Keno autoclave, which is constructed from 347 SS and has a volume of 68 liters. The autoclave has the capability of simultaneously loading up to three 304SS manifolds, where each manifold can support fifty 304 SS specimen module assemblies, for a total of 150 specimens. A schematic of a module assembly is shown in Figure 2. The load on each specimen is created by the pressure differential across a sliding seal on a piston connected to the specimen, where internal pressure of the autoclave is on one side and atmospheric pressure is on the other side of the manifold. On failure, the piston and specimen cause a numbered indicator ball (i.e., "Keno") to be ejected into the manifold. The indicator ball runs down the manifold into a track, past a sensor (which records the time of failure), and into a tube where it is stored so the failure sequence is known.

The level of stress applied to an individual specimen depends on the autoclave pressure and cross sectional area of the specimen gage. The load on each specimen is calculated as:

$$
\text { Applied Load }=\left(\text { Pressure }_{\text {water }}-\text { Pressure }_{\text {atmospherc }}\right) *(\text { Cross-Sectional Area of Module Seal })
$$

The applied stress is determined by dividing the applied load by the cross sectional area of the specimen gage.

The mixed salt solution composition was determined in a parallel study designed to closely simulate saturated Yucca Mountain ground water. The concentration of the Keno solution is $15 \%$ of the saturated concentration used in parallel SCC growth rate studies. [1]

$$
\sim 25 \%
$$

Two runs of Keno testing were performed. A smaller initial matrix of 50 specimens was tested first at $125^{\circ} \mathrm{C}$. The results from this small matrix were used to determine the stress levels and material conditions used in the following larger scale run $\left(150\right.$ specimens) performed at $105^{\circ} \mathrm{C}$. The matrix of specimens is shown in Table 1 . In addition to the as-received Alloy 22 and as-received Titanium Grade 7,20\% cold worked specimens and as-machined + shot peened specimens of both materials were also tested. Additionally, type $316 \mathrm{NG}$ stainless steel in the as-received and shot peened conditions was tested. Finally, as a reference / baseline condition, sensitized type 304 stainless steel was tested in the as-received and shot peened conditions. Shot peening was performed on the machined and cleaned specimens using GP60 glass pellets to an intensity of $6-8 \mathrm{~N}$ (several thousands of an inch depth). Shot peening servies were provided by Metal Improvement, Carlstadt, NJ.

The full matrix (Run 2) allowed investigation of the effect of material, applied stress, welded regions, crevice geometry, surface finish, cold work, and aging treatments designed to produce topologically close-packed phases (TCP) and long range ordering (LRO) in Alloy 22. Welded specimens were centered on the fusion line so that the specimen gage included both the weld and the heat affected zone (HAZ), as shown by the schematic in Figure 3. The TCP and LRO heat treatments were suggested by previous studies performed at Lawrence Livermore National Laboratory (LLNL). [2,3] The TCP heat treatment applied was $700^{\circ} \mathrm{C}$ for 175 hrs. The LRO heat treatment involved $1000 \mathrm{hrs}$ at $520^{\circ} \mathrm{C}$. Due to the time required for the heat treatment of the LRO specimens, they were added to the autoclave several weeks after the Keno testing initiated. (This difference in testing time for the LRO specimens is evident in the time-to-failure plots to be presented). In an effort to produce a tight crevice on the tensile specimen surfaces, creviced specimens were plastically pre-strained to $93 \%$ of the intended SCC experiment stress. After pre-straining, crevices were produced using 0.75 inch diameter Teflon barstock that had the center drilled out to the diameter specification of its respective specimen. The Teflon cylinders were then cut in half lengthwise and the two halves were clamped onto the specimens using stiff titanium wire. Diffusion of oxygen through bulk Teflon at $105^{\circ} \mathrm{C}$ was assumed negligible.

A pressuring gas was used to create the internal pressure in the autoclave due to the lack of substantial vapor pressure at $105-125^{\circ} \mathrm{C}$. An initial pressure of 900 psig was used to produce moderately high stresses in most specimens. Because of the higher autoclave gas pressure, the gas mixture was altered to avoid producing an unrealistically high fugacity of oxygen. A mass flow controller was used to mix about 1 part air with 61.2 parts of nitrogen to produce $\sim 1$ atmosphere "partial pressure" of air at $900 \mathrm{psig}$ in the $125^{\circ} \mathrm{C}$ salt solution. The pressure of

the gas mixture was increased to about $2600 \mathrm{psi}$ using a gas booster and stored in a gas cylinder. The pressure regulator controlled the inlet pressure to the autoclave, and a needle valve was used to maintain a stable flow rate 
through the autoclave of about $50-100 \mathrm{sccm}$. Temperature was controlled using a three-zone, independent, multiple band heater system on the autoclave, with temperature monitored at multiple locations within the autoclave to ensure temperature uniformity.

Time-to-failure results are plotted as a function of the ratio of applied stress to yield stress in an attempt to normalize the large differences in yield strength between materials used in the study. Tensile tests were performed in $125^{\circ} \mathrm{C}$ air to determine applicable yield strength values. Yield strength results (used in ensuing time-to-failure plots) are presented in Table 3 .

\section{Results and Discussion}

\section{Initial Matrix Run 1 at $125^{\circ} \mathrm{C}$}

As expected, the sensitized 304 stainless steel specimens failed at the lowest applied stresses (54-60 ksi) and lowest failure times ( 0.5 to $285.9 \mathrm{hrs})$, as shown in Figure 4. Fracture surfaces for these specimens exhibited an intergranular morphology, as shown in Figure 5a. The Titanium Grade 7 specimens (as-received and as-received + shot peened conditions) also failed early in testing ( 0.7 to $49.8 \mathrm{hrs}$ ) and at relatively low applied stress (49-56 ksi), although at higher applied \%UTS than the sensitized 304 stainless steel specimens (92\% vs. $72-80 \%$, respectively). Examples of typical fracture surfaces for Titanium Grade 7 specimens are shown in Figure $5 \mathrm{~b}$.

The Keno system was depressurized and cooled after $885.5 \mathrm{hrs}$ of total testing to investigate the degree of salt encrustation and possible negative effects on ball drop. Inspection of the type 304SS manifold and modules revealed some isolated areas of severe corrosion and encrustation. A total of twenty specimen failures were observed in the manifold, but salt deposits had prevented ball drop in 5 instances (and thus prevented recording of the failure time). The 5 unrecorded failures are noted in Figure 4. The twenty failures included all the as-received and as-received + shot peened Titanium Grade 7 and sensitized 304 stainless steel specimens. Temperature settings were lowered from the initial $125^{\circ} \mathrm{C}$ to $105^{\circ} \mathrm{C}$ to eliminate boiling of solution as it escapes past the seals on specimen failure, thus reducing the formation of the salt deposit. Cumulative experiment time was re-started at $885.5 \mathrm{hrs}$ in parallel with the pressure increase to $1000 \mathrm{psi}$. No additional failures occurred at $1000 \mathrm{psi}$. Pressure was increased to $1100 \mathrm{psi}$ at $1003.5 \mathrm{hrs}$. No failures occurred during the $318 \mathrm{hrs}$ at $1100 \mathrm{psi}$.

At $1321 \mathrm{hrs}$, the system pressure was increased to 1200 psi. Several cold worked Titanium Grade 7 and 316 NG stainless steel (both the as-received and shot peened conditions) failed over the next several days due to problems with the pressure regulator (Specimen failure stresses included in Table 1). These failures are likely overload failures. The sensitivity and instability of the pressure regulator worsened with time. Additionally, pressure drift increased vs. time, and was especially pronounced after the addition of new solution, presumably because of the reduced gas space in the autoclave. It is likely that the $316 \mathrm{NG}$ stainless steel specimens failed by ductile overload. Although the ultimate tensile strength was not measured in this program, an average value for three heats of $316 \mathrm{NG}$ stainless steel suggests an ultimate tensile strength of $\sim 75 \mathrm{ksi}$ at $\sim 100^{\circ} \mathrm{C}$. Failures occurred between 1412 and 1524 hrs (one failure occurred at 1922 hours). The system pressure during this time period was $\sim 1200$ to $1300 \mathrm{ksi}$, translating to applied specimen stresses between 68 to $75 \mathrm{ksi}$. No intergranular fracture was observed by scanning electron microscopy, confirming the occurrence of overload failure. Typical images representative of the failure surfaces for the overloaded 316 NG stainless steel specimens are presented in Figure 6a.

At $1922 \mathrm{hrs}$, the system pressure during Initial Run 1 drifted up to $1600 \mathrm{psi}$, which overloaded most of the remaining unfailed specimens. Thirteen specimens failed during the overload, including the as-received Alloy 22 (6 specimens), as-received + shot peened Alloy 22 (4 specimens), the remaining cold worked Titanium Grade 7 (2 specimens) and the last $316 \mathrm{NG}$ stainless steel specimen. Only the $20 \%$ cold worked Alloy 22 (6 specimens) remained unfractured. The system pressure reached 1600 psi due to problems with the regulator, translating to an applied stress of $111-117 \mathrm{ksi}$ (depending on the exact gage diameter) for the Alloy 22 specimens (all conditions). The $125^{\circ} \mathrm{C}$ air tensile strengths for the as-received and cold worked Alloy 22 were $104 \mathrm{ksi}$ and $133 \mathrm{ksi}$, respectively (also measured in this program using the same specimen geometry). The tensile strength for the cold worked Alloy 22 specimens was not exceeded during the overload; these 6 specimens are the only ones that did not fail in Run 1 . Microvoid coalescence typical of ductile overload failure is the dominant fracture feature for the overloaded Alloy 22 specimens; typical examples are presented in Figure $6 \mathrm{~b}$. 
Despite the trials and errors during the Preliminary Run 1, useful SCC information was still obtained. The SCC resistance of Alloy 22 is evident in the plot of failure stress vs. time-to-failure in Figure 4. Alloy 22 specimens exhibited the highest failure stress and longest time-to-failure. All of the Alloy 22 failures that occurred at 1922 hrs were due to the system overload and not due to SCC (the cold worked Alloy 22 specimens did not fail).

Statistical analysis using a Weibull distribution indicates that shot peening did not significantly affect time-to-failure for sensitized 304SS or Titanium Gr 7. An example of the statistical analysis for sensitized 304SS is shown in Figure 7 , where the $95 \%$ confidence bands are included. The lack of overlap of the confidence bands indicates a nil effect of shot peening on time-to-failure for this condition.

\section{Full Matrix Run 2}

Based on the experience gained in Run 1, several modifications were made to improve the Keno systems prior to the Full Run 2. A new pressure regulator was installed to provide better control of the system pressure. The system temperature was lowered to $105^{\circ} \mathrm{C}$, which is slightly less than the solution boiling point. This change in temperature prevented salt deposit formation on the manifold, allowing the balls to fall freely falf and to be correctly recorded by the data acquisition system. An improved system for monitoring autoclave solution level was installed. Additionally, a pressure transducer was installed, allowing computer acquisition and close monitoring of pressure data. Installation of a back pressure regulator was added as a safety measure.

The applied stress was lowered from Run 1 (Table 1) to Full Matrix Run 2 (Table 2) for sensitized 304SS and Titanium Gr 7 in an effort to reduce the early failures observed in Run 1. This experiment has run 2340 hrs to date, producing 40 specimen failures. A summary of the results is plotted in Figure 5 . Note that time zero begins at 1000 psi in Figure 8, and that the pressure was increased to $1500 \mathrm{psi}$ (the target value) at 168.5 hrs. Several 304SS and Titanium Gr 7 failures occurred soon after the increase to $168.5 \mathrm{hrs}$, suggesting that $168.5 \mathrm{hrs}$ is a more accurate "time zero". Increased applied stress decreased time-to-failure for the as-received Titanium Gr 7 specimens, as shown in Figure 8. Note that one as-received Titanium Gr 7 specimen remains unfailed after 2340 hrs.

Again, the SCC resistance of the Alloy 22 and $316 \mathrm{NG}$ materials is evident. No failures have occurred for any condition of these two materials. To further investigate the SCC resistance of these materials, the autoclave was cooled and emptied at $2340 \mathrm{hrs}$. The manifolds were removed from the autoclave and several unfailed $316 \mathrm{NG}$ and Alloy 22 specimens were removed from the manifolds, including as-received $316 \mathrm{NG}$, as-received Alloy 22, LRO Alloy 22, TCP Alloy 22, and welded Alloy 22 specimens in the highest stress conditions. All removed specimens were shiny with no evidence of corrosion or cracking. No SCC cracks or large pits were observed on the surfaces of these specimens using dye penetrant analysis. Limited small regions of damage (finer than the surface finish) were observed on some of the specimens (both $316 \mathrm{NG}$ and Alloy 22), but it is not known if the damage was produced during machining or during the environmental cracking experiment.

Statistical analysis showed that crevicing did not significantly effect the time-to-failure for the sensitized 304SS and the Titanium Gr 7 specimens, as shown by the overlapping confidence intervals. An example of this analysis is shown for the sensitized 304SS specimens in Figure 9. However, the slope of the Weibull distribution was affected by the presence of the crevice, as shown in the figure. Larger sample sizes are needed to further investigate the crevice effect.

\section{Conclusions}

1. Alloy 22 and $316 \mathrm{NG}$ exhibit outstanding SCC resistance in hot concentrated salt solution ( $\mathrm{pH}=10.3$ ) designed to simulate the chemistry of concentrated Yucca Mountain ground water.

2. Sensitized 304SS is highly susceptible to SCC in this environment.

3. Titanium Grade 7 is susceptible to SCC in this environment, particularly at very high \% UTS.

4. Shot peening did not effect time-to-failure for 304SS and Titanium Grade 7, as shown by the preliminary matrix results. 


\section{Acknowledgments}

Statistical support for this research was provided by Necip Doganaskoy at G.E. Corporate Research \& Development Center.

\section{References}

1. P.L. Andresen, P.W. Emigh, L.M. Young, "Stress Corrosion Cracking of Annealed and Cold Worked Titanium Grade 7 and Alloy 22 in $110^{\circ} \mathrm{C}$ Concentrated Salt Environments", Corrosion 2001, Paper No. 1130, (Houston, TX: National Association of Corrosion Engineers, 2001).

2. T.S.E. Summers, M.A. Wall, M. Kumar, S.J. Matthews, and R.B. Rebak, "Phase Stability and Mechanical Properties of ALLOY 22 Alloy Aged in the Temperature Range 590 to $760^{\circ} \mathrm{C}$ for 16,000 hours," Lawrence Livermore National Laboratory Report \#UCRL-JC-130816, in Scientific Basis for Nuclear Waste Management XXII, ed. by David J. Wronkiewicz and Joon H. Lee, Materials Research Society (1999), 919-926.

3. T.S.E. Summers, personal communication, December 2000.

Table 1. Initial Run 1

\begin{tabular}{|l|l|c|c|}
\hline Material & \multicolumn{1}{|c|}{ Condition } & $\begin{array}{c}\text { Max Applied Stress } \\
\text { (ksi) }\end{array}$ & $\begin{array}{c}\text { Total } \\
\text { Specimens }\end{array}$ \\
\hline Alloy-22 & As-received & 115 & 6 \\
\hline & AR + 20\% cold work & 115 & 6 \\
\hline & AR + shot peened & 115 & 4 \\
\hline Ti-Grade 7 & As-received & 49,55 & 6 \\
\hline & AR + 20\% CW & 67,88 & 6 \\
\hline & AR + shot peened & 56 & 4 \\
\hline NG 316 SS & As-received & 69,90 & 4 \\
\hline & AR + shot peened & 69 & 4 \\
\hline 304 SS & Sensitized & 54,60 & 6 \\
\hline & Sensitized + shot peened & 54,60 & 4 \\
\hline Total & & & $\mathbf{5 0}$ \\
\hline
\end{tabular}


Table 2. Full Autoclave Run (Run 2)

\begin{tabular}{|c|c|c|c|c|c|c|}
\hline \multirow{3}{*}{\begin{tabular}{|l} 
Material \\
Alloy-22 \\
\end{tabular}} & \multirow[t]{3}{*}{ Condition } & \multirow{3}{*}{\begin{tabular}{|l} 
Finish \\
RMS
\end{tabular}} & \multicolumn{3}{|c|}{ Specimens per Condition } & \multirow[t]{3}{*}{$\begin{array}{c}\text { Total } \\
\text { Specimens } \\
\end{array}$} \\
\hline & & & \multicolumn{3}{|c|}{ System Pressure $=1500$ psi } & \\
\hline & & & $85 \mathrm{ksi}$ & $93 \mathrm{ksi}$ & $100 \mathrm{ksi}$ & \\
\hline & As-received & 150 & 6 & 6 & 6 & 18 \\
\hline & As-received & 72 & & 6 & & 6 \\
\hline & $\mathrm{AR}+$ Thermal treat 1 (TCP) & 150 & 6 & 6 & & 12 \\
\hline & AR + Thermal treat 2 (LRO) & 150 & 6 & 6 & & 12 \\
\hline & $\mathrm{AR}+20 \% \mathrm{CW}+$ Thermal treat $2(\mathrm{LRO})$ & & & 6 & & 6 \\
\hline & $20 \%$ Cold worked & & & 6 & & 6 \\
\hline & AR + Creviced & 150 & 6 & 6 & & 12 \\
\hline & AR + Thermal treat $1+$ Creviced & 150 & 6 & 6 & & 12 \\
\hline & Weld and HAZ & 150 & 6 & 6 & & 12 \\
\hline Ti-Grade 7 & & & $40 \mathrm{ksi}$ & $45 \mathrm{ksi}$ & $50 \mathrm{ksi}$ & \\
\hline & As-received & 150 & 6 & 6 & 5 & 17 \\
\hline & Creviced & 150 & & 6 & & 6 \\
\hline NG 316 SS & & & $65 \mathrm{ksi}$ & $70 \mathrm{ksi}$ & & \\
\hline & As-received & 150 & 6 & 6 & & 12 \\
\hline & As-received & 72 & & 6 & & 6 \\
\hline & Creviced & 150 & & 6 & & 6 \\
\hline 304 SS & & & $45 \mathrm{ksi}$ & $50 \mathrm{ksi}$ & & \\
\hline & Sensitized & 150 & 6 & 6 & & 12 \\
\hline & Sensitized + creviced & 150 & & 6 & & 6 \\
\hline Total & & & & & & 161 \\
\hline
\end{tabular}

Table 3. Tensile Properties in Air

\begin{tabular}{|l|c|c|}
\hline \multicolumn{1}{|c|}{ Material/Condition } & $\begin{array}{c}\text { Yield Strength } \\
(\mathrm{ksi})\end{array}$ & $\begin{array}{c}\text { Tensile Strength } \\
(\mathrm{ksi})\end{array}$ \\
\hline Alloy-22 As received & $47\left(125^{\circ} \mathrm{C}\right)$ & $104\left(125^{\circ} \mathrm{C}\right)$ \\
\hline Alloy-22 As received $+20 \% \mathrm{CW}$ & $125\left(125^{\circ} \mathrm{C}\right)$ & $133\left(125^{\circ} \mathrm{C}\right)$ \\
\hline Alloy-22 As received $+\mathrm{HT} 1\left(700^{\circ} \mathrm{C} / 175 \mathrm{~h}\right)$ & $49\left(105^{\circ} \mathrm{C}\right)$ & $107\left(105^{\circ} \mathrm{C}\right)$ \\
\hline Alloy-22 As received $+\mathrm{HT} 2\left(520^{\circ} \mathrm{C} / 1000 \mathrm{~h}\right)$ & $70\left(105^{\circ} \mathrm{C}\right)$ & $149\left(105^{\circ} \mathrm{C}\right)$ \\
\hline Alloy-22 20\% CW $+\mathrm{HT} 2\left(520^{\circ} \mathrm{C} / 1000 \mathrm{~h}\right)$ & $133\left(105^{\circ} \mathrm{C}\right)$ & $179\left(105^{\circ} \mathrm{C}\right)$ \\
\hline 316 NG As received & $28.7\left(125^{\circ} \mathrm{C}\right)^{*}$ & - \\
\hline Titanium Gr 7 As-received & $36\left(125^{\circ} \mathrm{C}\right)$ & $53\left(125^{\circ} \mathrm{C}\right)$ \\
\hline Titanium Gr 7 20\% CW & $72.5\left(125^{\circ} \mathrm{C}\right)$ & $75.5\left(125^{\circ} \mathrm{C}\right)$ \\
\hline 304SS Sensitized $\left(621^{\circ} \mathrm{C} / 24 \mathrm{~h}\right)$ & $42.5\left(125^{\circ} \mathrm{C}\right)$ & $75\left(125^{\circ} \mathrm{C}\right)$ \\
\hline
\end{tabular}

* Interpolated using RT and $288^{\circ} \mathrm{C}$ data 


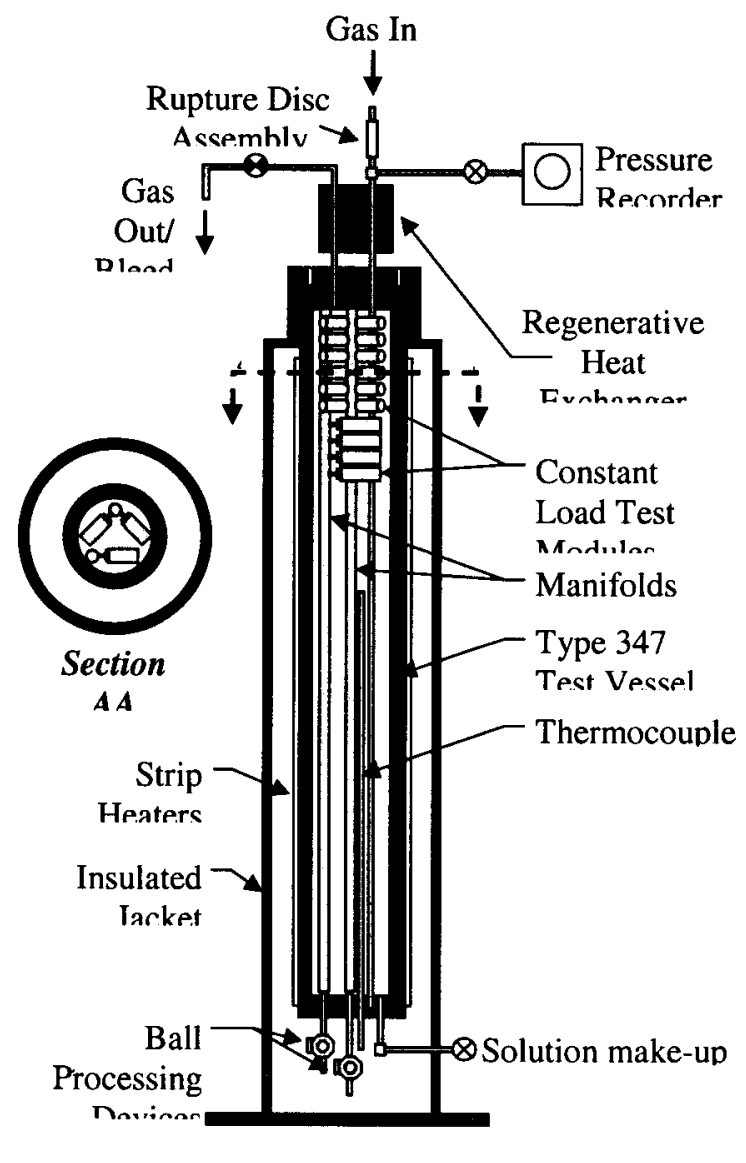

Figure 1. Schematic cross section of Keno autoclave for smooth constant load testing.

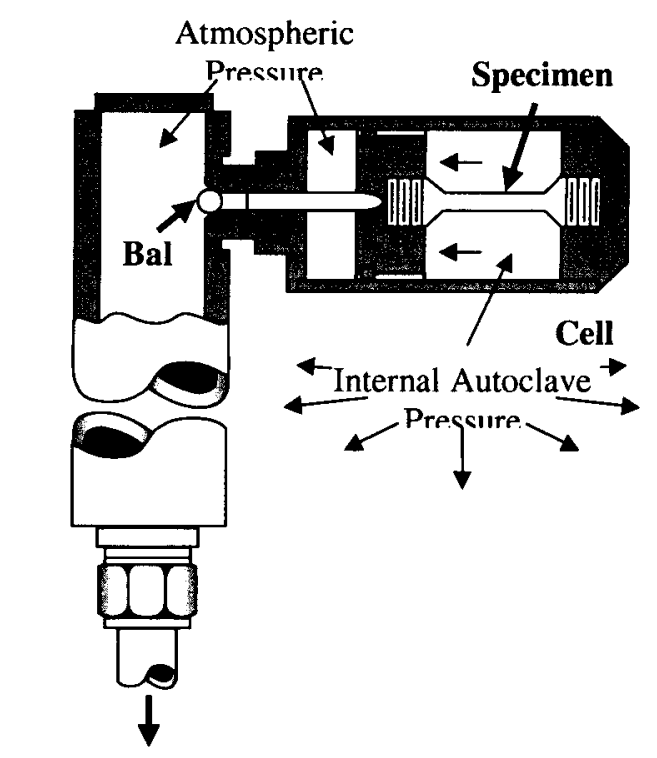

To ball counter and

data nemisition

Figure 2. Schematic cross section of Keno smooth constant load module assembly and tensile specimen illustrating the loading technique of differential pressure.

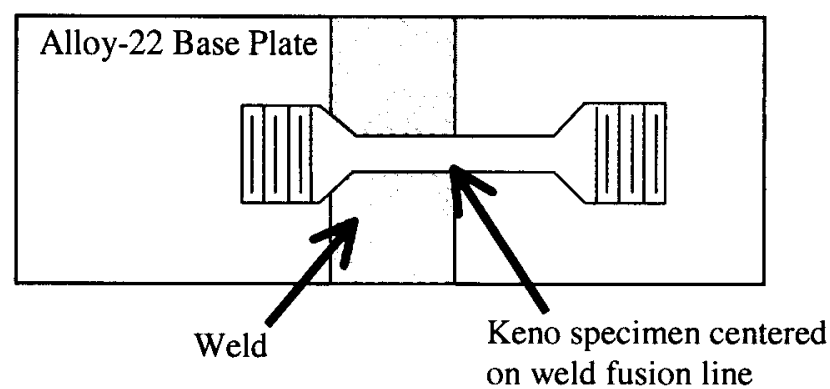

Figure 3. Specimen placement in Alloy-22 welded plate. Tensile direction is perpendicular (transverse) to weld pass direction. 


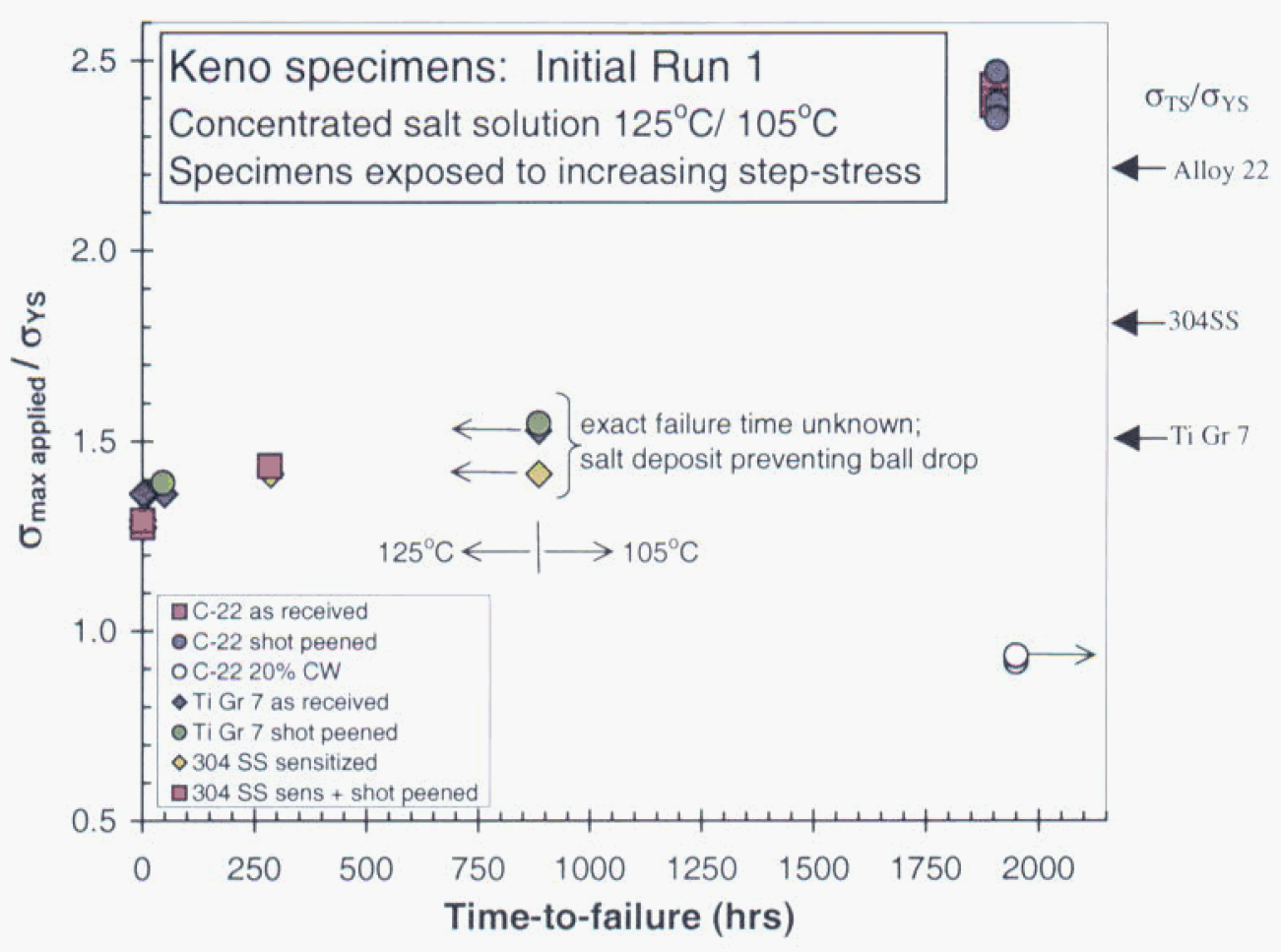

Figure 4. Time-to-failure vs. Applied stress ratio for Initial Run 1. Salt deposit formation prevented failure time acquisition for several failures at $125^{\circ} \mathrm{C}$. System overload (due to a faulty pressure regulator) produced ductile overload failures in the Alloy 22 specimens.

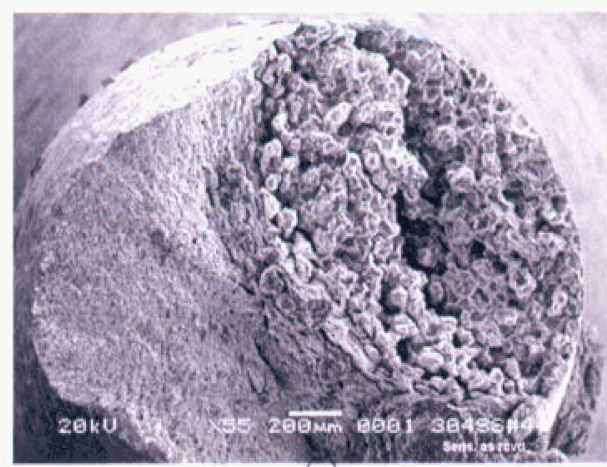

(a)

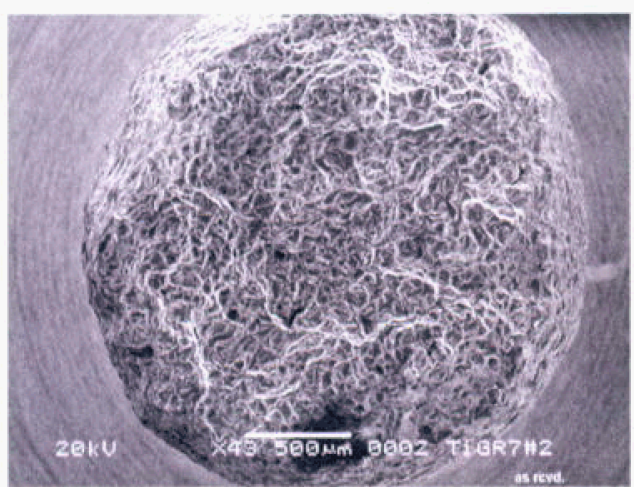

(c)

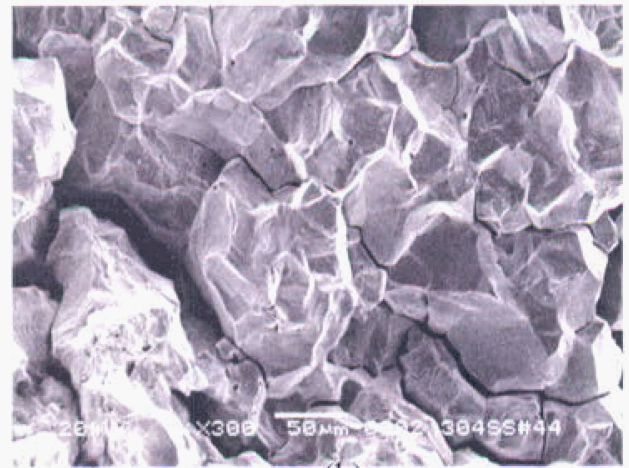

(b)

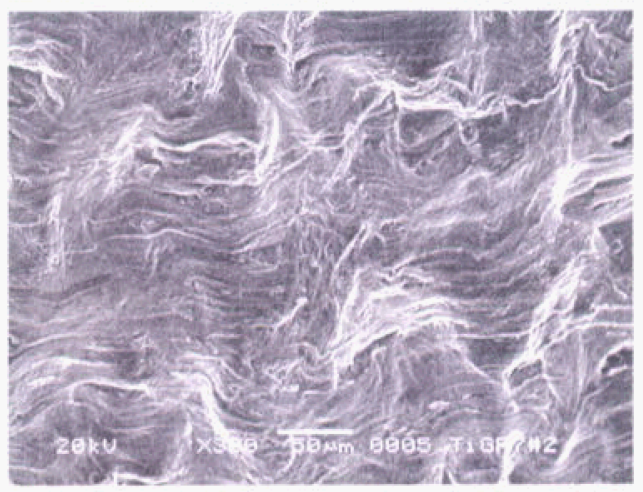

(d)

Figure 5. SCC surfaces for failed Keno specimens (a) and (b) Sensitized 304SS; (c) and (d) Titanium Gr7. 


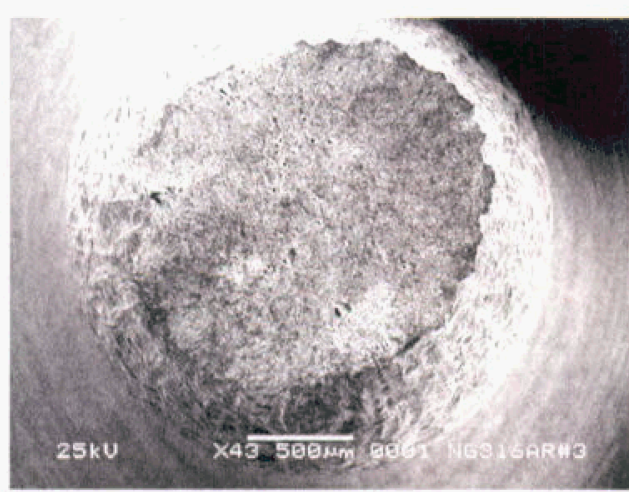

(a)

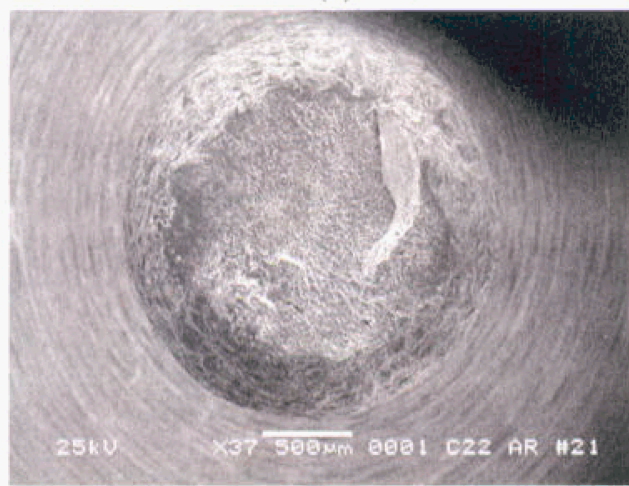

(c)

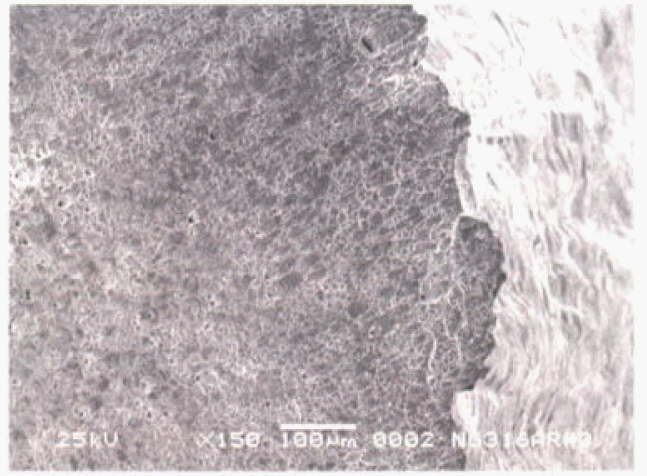

(b)

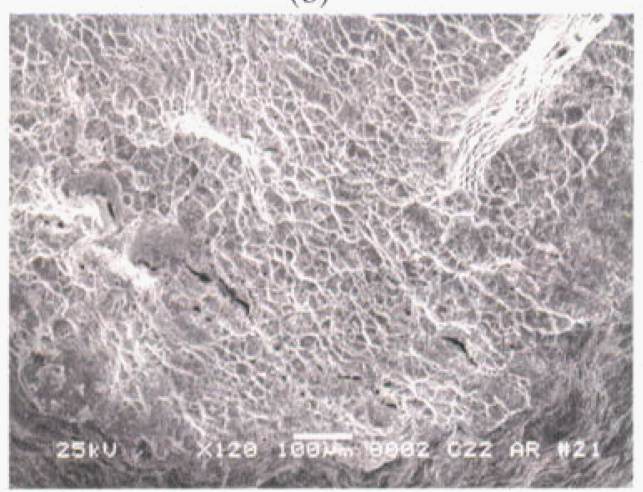

(d)

Figure 6. Fracture surfaces of ductile overload failures of Keno specimens (a) and (b) 316NG stainless steel; (c) and (d) Alloy 22.

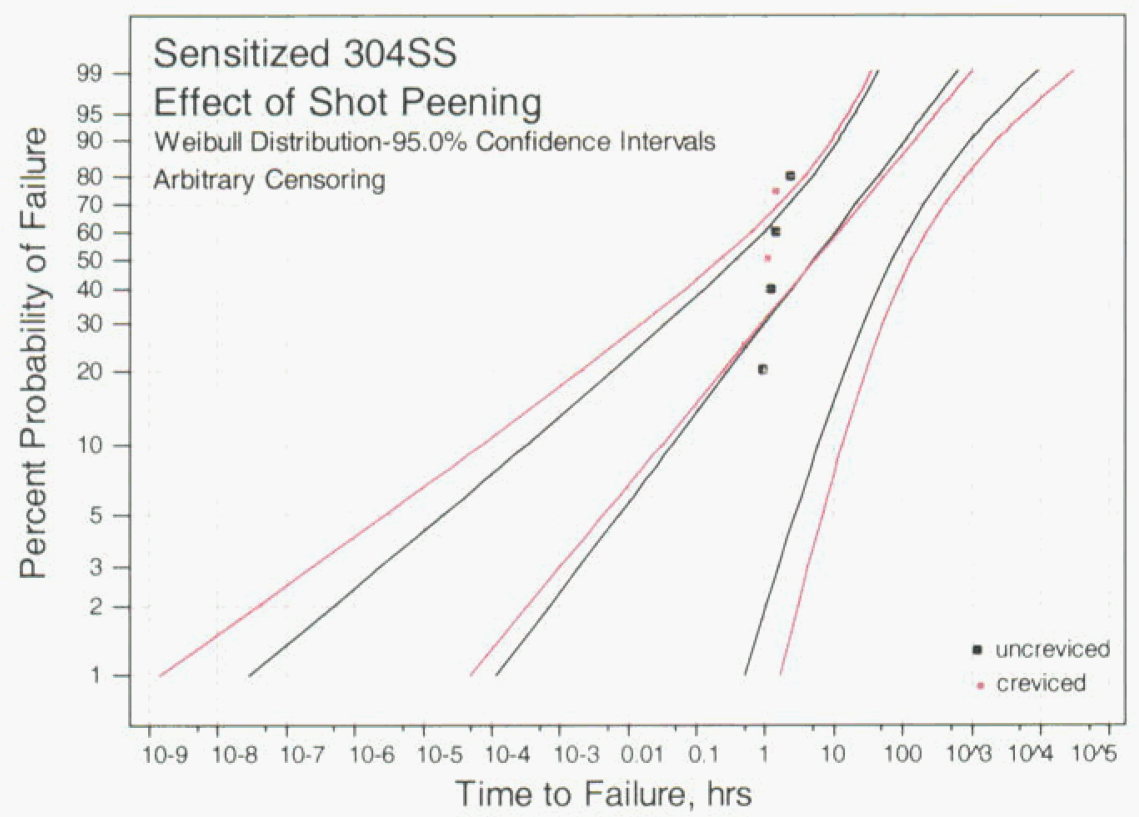

Figure 7. Weibull plot showing \% probability of failure vs, time-to-failure (hours) for as-received and shot peened sensitized 304SS specimens. The overlapping confidence intervals indicate no effect of shot peening on time-to-failure. 


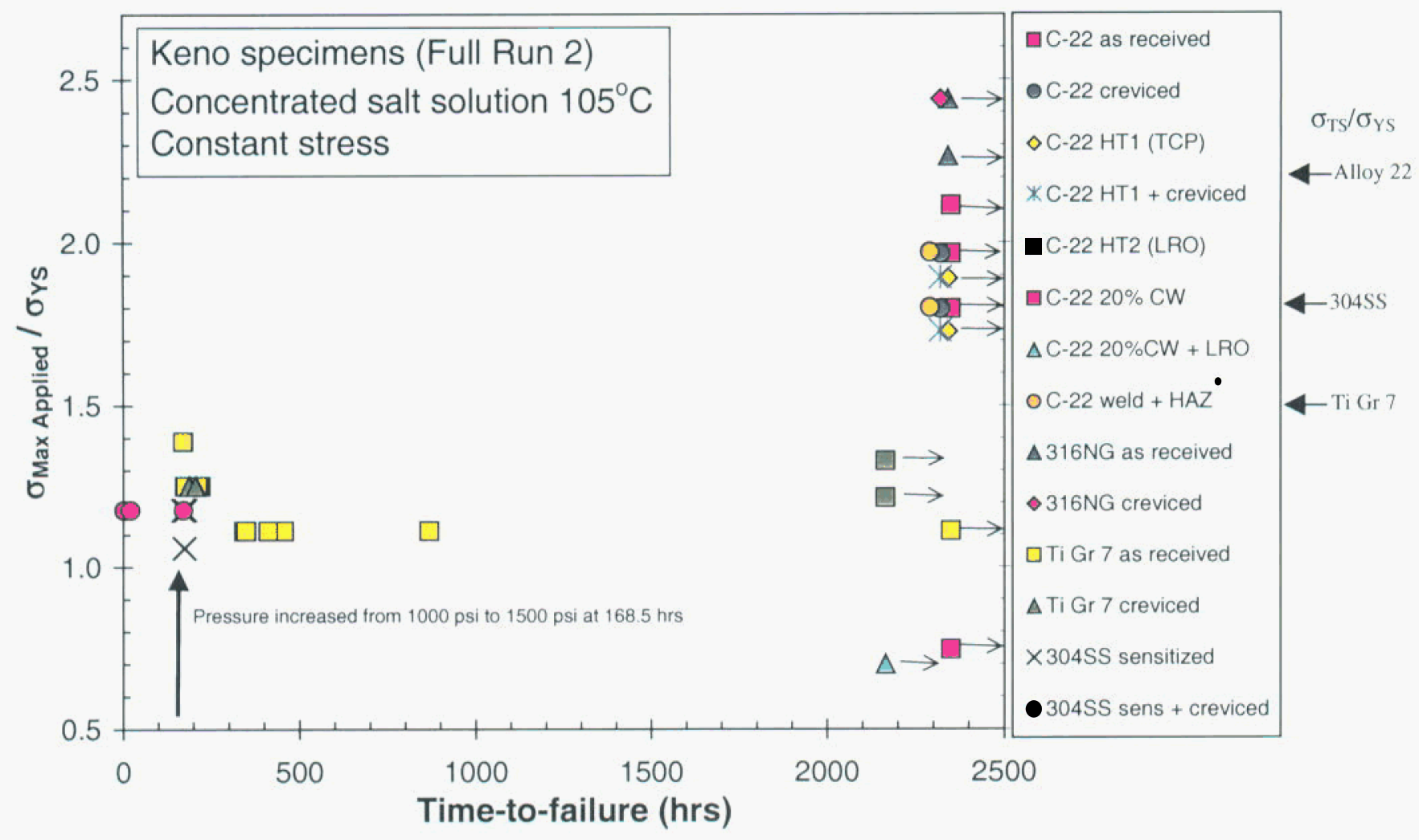

Figure 8. Time-to-failure vs. Applied stress ratio for Full Matrix Run 2. Forty specimens have failed to date, while 121 specimens remain unfailed.

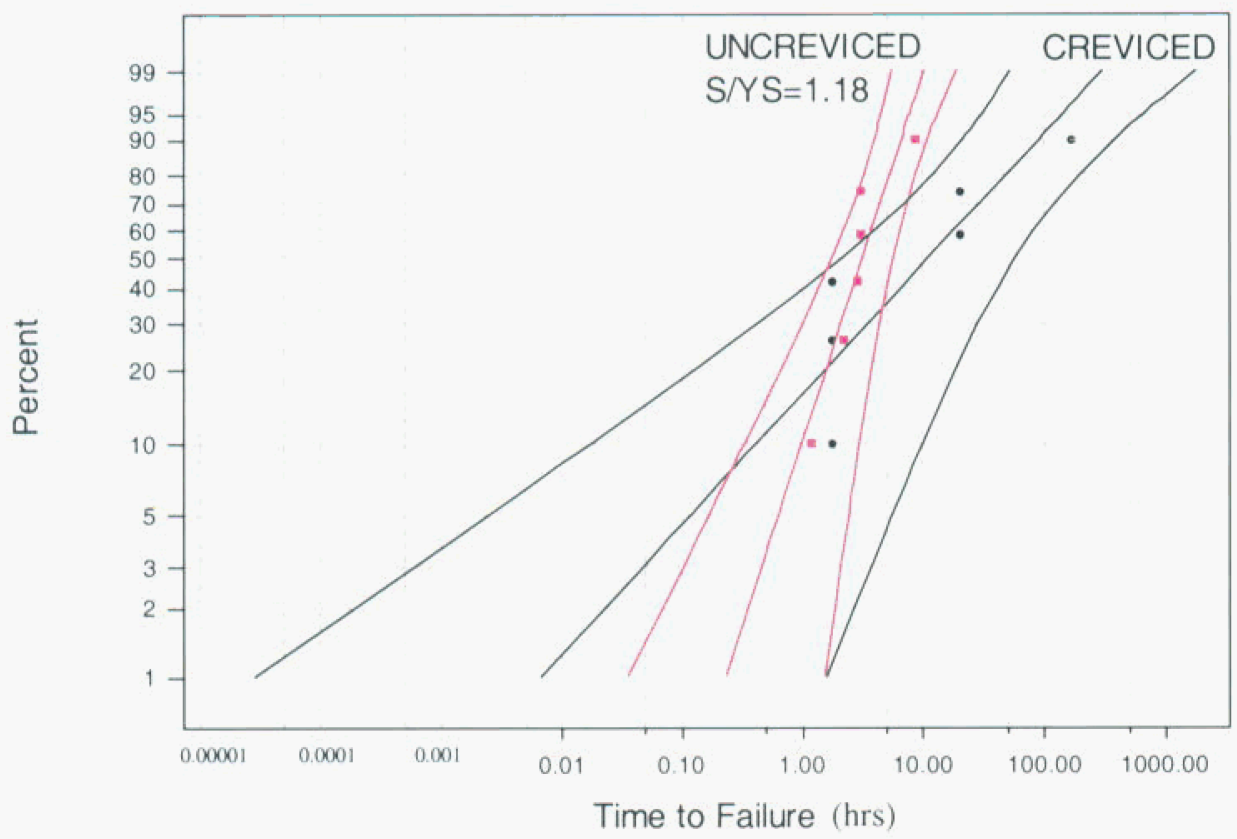

Figure 9. Weibull plot showing \% probability of failure vs. time-to-failure (hours) for as-received and as-received + creviced sensitized $304 \mathrm{SS}$ specimens. The $95 \%$ confidence bands are included. The overlapping confidence intervals indicate no statistically significant effect of crevicing on time-to-failure for sensitized 304SS in hot mixed salt solution. 